\title{
Turkic Soundscapes
}

The Turkic soundscape is both geographically huge and culturally diverse (twentyeight countries, republics and districts extending from Eastern Europe through the Caucasus and throughout Central Asia). Although the Turkic peoples of the world can trace their linguistic and genetic ancestries to common sources, their extensive geographical dispersion and widely varying historical and political experiences have generated a range of different expressive music forms. In addition, the breakup of the Soviet Union and increasing globalization have resulted in the emergence of new viewpoints on classical and folk traditions, Turkic versions of globalized popular culture, and re-workings of folk and religious practices to fit new social needs. In line with the opening up of many Turkic regions in the post-Soviet era, awareness of scholarship from these regions has also increased. Consisting of twelve individual contributions that reflect the geographical breadth of the area under study, the collection addresses animist and Islamic religious songs; the historical development of Turkic musical instruments; ethnography and analysis of classical court music traditions; cross-cultural influences throughout the Turkic world; music and mass media; and popular music in traditional contexts. The result is a well-balanced survey of music in the Turkic-speaking world, representing folk, popular and classical traditions equally, as well as discussing how these traditions have changed in response to growing modernity and cosmopolitanism in Europe and Central Asia.

Razia Sultanova is a Research Fellow at the University of Cambridge Faculty of Music and Visiting Professor at Moscow State Conservatory, Kazakh National University of Arts (Astana) and Ahmet Yassawi Kazakh-Turkish University (Turkistan). Her research examines culture, sound, place and authenticity in the Turkic-speaking world across Central Asia, the Caucasus, Afghanistan, Iran and Turkey.

Megan Rancier is a Lecturer of Ethnomusicology at Bowling Green State University (Bowling Green, Ohio). She earned a Ph.D. in ethnomusicology from the University of California, Los Angeles. Her research interests focus on Central Asia, particularly Kazakhstan, and intersections between national identity narratives, traditional musical instruments and popular music. 


\section{SOAS Musicology Series}

Series Editors:

Rachel Harris, SOAS, University of London, UK

Rowan Pease, SOAS, University of London, UK

SOAS Musicology Series is today one of the world's leading series in the discipline of ethnomusicology. Our core mission is to produce high-quality, ethnographically rich studies of music-making in the world's diverse musical cultures. We publish monographs and edited volumes that explore musical repertories and performance practice, critical issues in ethnomusicology, sound studies, historical and analytical approaches to music across the globe. We recognize the value of applied, interdisciplinary and collaborative research, and our authors draw on current approaches in musicology and anthropology, psychology, media and gender studies. We welcome monographs that investigate global contemporary, classical and popular musics, the effects of digital mediation and transnational flows.

For a full list of recent titles, please visit www.routledge.com/music/series/ SOASMS

Sounding the Dance, Moving the Music: Choreomusicological Perspectives on Maritime Southeast Asian Performing Arts

Mohd Anis Md Nor and Kendra Stepputat

Flamenco, Regionalism and Musical Heritage in Southern Spain

Matthew Machin-Autenrieth

The Women of Quyi

Francesca R. Sborgi Lawson

The Music of Malaysia

Patricia Matusky and Tan Sooi Beng

Theory and Practice in the Music of the Islamic World: Essays in Honour of Owen Wright

Edited by Rachel Harris and Martin Stokes

Singing the Gospel along Scotland's North-East Coast, 1859-2009

Frances Wilkins

Turkic Soundscapes: From Shamanic Voices to Hip-Hop

Edited by Razia Sultanova and Megan Rancier 


\section{Turkic Soundscapes}

From Shamanic Voices to Hip-Hop

\section{Edited by Razia Sultanova and Megan Rancier}

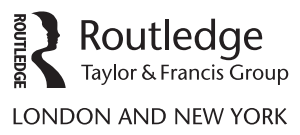


First published 2018

by Routledge

2 Park Square, Milton Park, Abingdon, Oxon OX14 4RN

and by Routledge

711 Third Avenue, New York, NY 10017

Routledge is an imprint of the Taylor \& Francis Group, an informa business

(C) 2018 selection and editorial matter, Razia Sultanova and Megan Rancier; individual chapters, the contributors

The right of Razia Sultanova and Megan Rancier to be identified as the authors of the editorial material, and of the authors for their individual chapters, has been asserted in accordance with sections 77 and 78 of the Copyright, Designs and Patents Act 1988.

All rights reserved. No part of this book may be reprinted or reproduced or utilised in any form or by any electronic, mechanical, or other means, now known or hereafter invented, including photocopying and recording, or in any information storage or retrieval system, without permission in writing from the publishers.

Trademark notice: Product or corporate names may be trademarks or registered trademarks, and are used only for identification and explanation without intent to infringe.

British Library Cataloguing in Publication Data

A catalogue record for this book is available from the British Library

Library of Congress Cataloging in Publication Data

Names: Sultanova, Razia. | Rancier, Megan.

Title: Turkic soundscapes : from shamanic voices to hip-hop / edited by Razia Sultanova and Megan Rancier.

Description: Abingdon, Oxon ; New York, NY : Routledge, 2018.

Series: SOAS musicology series | Includes bibliographical references and index.

Identifiers: LCCN 2017049218| ISBN 9781138062405 (hardback) |

ISBN 9781315161655 (ebook)

Subjects: LCSH: Turkic peoples-Music—History and criticism.

Music - Middle East x History and criticism. | Music—Europe,

Western x History and criticism. | Music_-Turkish influences.

Classification: LCC ML3545.T87 2018 | DDC 780.917/4943 — dc23

LC record available at https://lccn.loc.gov/2017049218

ISBN: 978-1-138-06240-5 (hbk)

ISBN: 978-1-315-16165-5 (ebk)

Typeset in Times New Roman

by Keystroke, Neville Lodge, Tettenhall, Wolverhampton 


\section{Contents}

List of figures

vii

List of tables

ix

List of musical examples

xi

Notes on contributors

xiii

Acknowledgements

xvii

Map of the Turkic-speaking world

xviii

Foreword by Duisen Kaseinov (Secretary General of Turksoy) xix

Foreword by Martin Stokes

1 Introduction: traditions and transformations in Turkic musical cultures

RAZIA SULTANOVA

\section{PART I}

Cultural foundations in music of the twenty-first century

2 The concept of makam-based melody and its problematic in musical analysis

OKAN MURAT ÖZTÜRK

3 The pedagogical system of Azerbaijani master musician Bahram Mansurov (1911-1985)

VIOLETTA YUNUSOVA

4 From popular tradition to pop diffusion: jahri zikr among teenagers in present-day Kazakhstan 
vi Contents

\section{PART II}

Turkic music in popular culture and mass media

5 Azerbaijani rap music and oral poetry between "the folk" and "the popular"

THOMAS SOLOMON

6 Mass music in Kazakhstan: the phenomenon and its interpretation

100 GULNAR ABDIRAKHMAN

7 Musical images of Istanbul from Fatih Akin's films and stage performances

IVANKA VLAEVA

\section{PART III}

Cross-cultural encounters in the Turkic-speaking world and beyond

8 From the spiritual to the profane and back: religious melodies and folksongs of Turkic peoples JÁNOS SIPOS

9 The Circumpontic Lezginka dance as a cultural phenomenon ALLA SOKOLOVA

10 The impact of Turkic musical culture on the music of Bulgaria TIMOTHY RICE

\section{PART IV}

Turkic music and national identities

11 Debating "national ownership" of musical instruments: the balalaika as a subject of ethnopolitical discourse ULRICH MORGENSTERN

12 New music of the Crimean Tatars: history and current status ABDULLAH AKAT

13 Ancient roots, modern nation-building: Kazakh spirituality and identity in the music of the Turan ensemble MEGAN RANCIER 


\section{Figures}

2.1 Traditional fret system with three regions, fret names, and alphanumeric notational symbols. Transformed natural signs in parentheses show lowered intonations of the related notes. The last line under the notes includes alternative names for frets

2.2 Graphic representation of the cyclic motion. In this motion, $\mathrm{BC}$ and $\mathrm{EC}$ take place on the same central fret/note. BC: beginning center, EC: ending center, arrow heads show possible paths for melodic figure formation

2.3 Positional melodic figures: repetition, neighbor motion, serial neighbor motion, double neighbor motion, and gap-filling. These figures always refer to the cyclic motion and form the uni-centric makam-tunes

2.4 Graphic representation of the linear motion. This manner of motion has typically two different central frets, $\mathrm{BC}$ : beginning center, EC: ending center

2.5 Orientational melodic figures: step, anticipation, skip, escape note, serial step, and leap. These figures refer to the linear motion and formation of the bi-centric makam-tunes

2.6 Beginning sections of the analysis examples 34

2.7 Ending sections of the analysis examples 34

2.8 Typical uni-centric makam-tune formation for Makam Rast. C1: the first and last center, BC: beginning center, EC: ending center. Makam Rast has only one single central fret/note for the beginning and ending of melodic motion

2.9a-c Typical bi-centric formation of the makam-tunes of: a) Neva, b) Hüseynî, c) Pençgâh $h_{\text {zaid }}$.n bi-centric makams, there are two types of makam-tune sections: 'positional' and 'orientational' 36

2.10 The typical tune formations for the multi-centric [compound] makam Mahur

2.11 A modeling of the basic relationship between theoretical makam concept and compositional or improvisational melodic sections

3.1 Bahram Mansurov

3.2 Letter from Bahram Mansurov 
Giovanni DE ZORZI - University "Ca' Foscari" of Venice - 08/02/2018

viii Figures

3.3 Bahram Mansurov at the lesson with author (1979) 47

3.4 Computer diagram of Bahram Mansurov's fragment Mahur-Hindi 56

5.1 A two-line meyxana refrain, showing rhythmic placement of text syllables

10.1 Bulgarian four-course tamburas

11.1 Jean-Baptiste Leprince. "Le Joueur de Balalaika." Oil on canvas, 1764. Paris, musée Cognacq-Jay

11.2 A Kazakh dombra from Semipalatinsk ("Kumiss and kitchen utensils and musical instrument dombra. S. Dudin. Semipalainsk, 1899.") Peter the Great Museum of Anthropology and

Ethnography (Kunstkamera), RAS. Coll. \# 1199-41 


\section{Tables}

2.1 Basic fret/perde/makam tunings and adjustments in $\begin{array}{ll}\text { fifteenth/sixteenth centuries } & 27\end{array}$

3.1 Tunings of Bahram Mansurov's tars 48

3.2 Bahram Mansurov's combinations of gushes in destgah Shur 51

3.3 The various combinations of gushe, played by Bahram Mansurov and his students 51

3.4 The predominant type of string in Shur destgah 53

3.5 Structure of destgah Mahur-Hindi (Bahram Mansurov) 55

3.6 Structure of destgah Mahur-Hindi (Valeh Ragimov) 55

5.1 Oləkbər, Pərviz and Elşən. "Meyxana deyişmə—binə toyu." [Competition meyxana -wedding.] Opening refrain and first two verses with refrains

5.2 Leyla və Dəyirman, "Sarı Gəlin" (from the album Azərimeyk, 2000) 87 
Review Copy - Not for Distribution

Giovanni DE ZORZI - University "Ca' Foscari" of Venice - 08/02/2018 


\section{Musical examples}

4.1 and 4.2 Ostinato of the zakir $r$-s and sacred hymn $\quad 67$

4.3 Zikr-i Halqa phrase 68

4.4 Execution of Zikr-i Halqa phrase 68

4.5 Fest variant of Zikr-i Halqa phrase 68

6.1 "Saryarka (Golden Steppe)" by Akseleu Seydimbekov 108

6.2 "Kara kempir" (Black Crone) by Altynbek Korazbaev (based on a poem by Zhaksylyk Satibekov) 109

8.1 The first line shows an eleven-syllable melody with a large descent in each section. The second and third lines show two-sectioned eleven- and eight-syllable melodies; their first section descends to (or near to) the final tone in a similar way as a) does, while the second section descends from a lower degree $\quad 139$

8.2 Two-sectioned, eleven-syllable melodies; at the end of the first section, the descent stops on C or D

8.3 A typical Tahtadji melody (Sipos 1994, No. 390) 141

8.4 Bektashis folksong (Sipos and Csáki 2009, No. 391) 142

8.5 Bektashis religious nefes (Sipos and Csáki 2009, No. 392) 142

8.6 The wedding song (parallel to the second nefes in the zikr) (Sipos 2001, No. 233)

8.7 Motives and a typical melody series of the küstdepti (from the Sipos Turkmen collection)

8.8 Simpler types of women's songs: a) lullaby (Sipos collection No. 177), b) läle (Sipos collection No. 77), c) lullaby (Sipos collection No. 127), d) mourning-song for the dead (Sipos collection No. 179), e) läle "tulip"-_song of girls) (Sipos collection No. 174)

8.9a Eleven-syllable, two-section Kyrgyz Carapazan song 147

8.9b Seven-syllable, four-section Kyrgyz Carapazan song 148

8.9c Eight-syllable, four-section Kyrgyz folksong 148

8.10 Karachay zikr (Sipos 2012, No. 20) 149

8.11 Karachay lullaby (Sipos 2012, No. 21) 150

9.1 Folk tune "Shamil's Dance" 158 
Giovanni DE ZORZI - University "Ca' Foscari" of Venice - 08/02/2018 xii Musical examples

9.2 Folk tune, often referred to as "Kabardinka" 159

9.3 Folk tune, generally known as "Akushinsky dance" 159

$\begin{array}{ll}9.4 \text { The folk tune "Elbrus Beauty" } & 160\end{array}$ 


\section{Contributors}

Gulnar Abdirakhman is an Associate Professor at the Department of Musicology of the Kazakh National University of Arts (Astana). She graduated from the Kurmangazy Kazakh National Conservatory in 1989, and in 1999 gained her $\mathrm{PhD}$ from the Mukhtar Auezov Kazakh Institute of Literature and Art (Almaty).

Abdullah Akat is Associate Professor and Director at Karadeniz Technical University (KTU) State Conservatory and Karadeniz Music Archive (KARMA). He serves as chair of the KTU Performing Arts Department and university senator in Trabzon, Turkey. His research focuses on Turkey (Black Sea), Caucasian music culture and Crimean Tatar music.

Giovanni De Zorzi is a Lecturer in Ethnomusicology at Ca' Foscari University in Venice. His main research areas are Ottoman and Central Asian traditions of classical and Sufi music. He plays the Ottoman ney flute (as a soloist and with his Ensemble Marâghî) while also undertaking field research, scientific writing and academic teaching.

Duisen Kaseinov has served as Secretary General of TURKSOY (the International Organization of Turkic Culture) since 2008. Kaseinov has been Rector at the Kurmangazy State Conservatory in Almaty (1987-1997), served as Minister of Culture of Kazakhstan (2003-2005) and has assumed executive functions within various NGOs.

Ulrich Morgenstern is Professor and Chair of History and Theory of Folk Music at the University of Music and Performing Arts Vienna, Department of Folk Music Research and Ethnomusicology. His research examines European folk music, ethno-organology, multipart instrumental music, history of scholarship, folk music in political movements, and revivalism in Austria, Germany and Russia.

Okan Murat Öztürk is Associate Professor at Baskent University State Conservatory (Ankara, Turkey). He is an academician and a master of Anatolian/ Turkish traditional musics. His main interests are traditional music styles of Anatolia, makam theory and the politics of music in the modernization period of Turkey. He has published various CDs and books. 
Megan Rancier is a Lecturer of Ethnomusicology at Bowling Green State University (Bowling Green, Ohio). She earned a PhD in ethnomusicology from the University of California, Los Angeles. Her research interests focus on Central Asia, particularly Kazakhstan, and intersections between national identity narratives, traditional musical instruments and popular music.

Timothy Rice is Emeritus Professor of Ethnomusicology at the University of California, Los Angeles. He specializes in the traditional music of the Balkans, especially Bulgaria and Macedonia. He has written on musical cognition, politics and music, meaning and music, mass media, music teaching and learning, and theory and method in ethnomusicology.

János Sipos is a Senior Research Fellow at the Institute for Musicology of the Hungarian Academy of Sciences, a Member of the Hungarian Academy of Arts and the International Council for Traditional Music, and lecturer at the Franz Liszt Music Academy. His research focuses on comparative analysis of the folk music of Turkic peoples.

Alla Sokolova is Professor at Adyghea State University Institute of the Arts, a member of the Russian Union of Composers, and author of over 250 scholarly and 200 popular works on Adyg and Cossack culture, Adyg traditional music and modern composition. She specializes in ethnomusicology, instrumental music and art history.

Thomas Solomon is Professor of Musicology at the University of Bergen. He has done field research in Bolivia on musical imaginations of ecology, place and identity, and in Istanbul on place and identity in Turkish hip-hop. He has also published on various theoretical topics in ethnomusicology and popular music studies.

Martin Stokes is King Edward Professor of Music at King's College London. His research interests include ethnomusicology and the anthropology of music, Middle Eastern and European popular music and culture, and social and cultural theory. He is currently working on theorizations of emotion and cultural intimacy.

Razia Sultanova is a Research Fellow at the University of Cambridge Faculty of Music and Visiting Professor at Moscow State Conservatory, Kazakh National University of Arts (Astana) and Ahmet Yassawi Kazakh-Turkish University (Turkistan). Her research examines culture, sound, place and authenticity in the Turkic-speaking world across Central Asia, the Caucasus, Afghanistan, Iran and Turkey.

Ivanka Vlaeva, $\mathrm{PhD}$, is Associate Professor at South-West University "Neofit Rilski", Blagoevgrad and Associate Member of the Institute of Art Studies Bulgarian Academy of Sciences, Sofia, Bulgaria. She teaches historical, theoretical and ethnomusicological courses. Her publications and research interests cover traditions and contemporary transformations of music in Bulgaria and Asia, archives and world music. 
Violetta Yunusova is Professor of the Foreign Music History Department at Moscow's Tchaikovsky State Conservatory. She graduated from the Academy of Arts in Ufa, and Leningrad (SPb) Institute of Theatre, Music and Cinema. Her research examines Azerbaijani instrumental Mugham improvisations and the creative process in Asian classical music. 
Review Copy - Not for Distribution

Giovanni DE ZORZI - University "Ca' Foscari" of Venice - 08/02/2018 


\section{Giovanni DE ZORZI - University
Acknowledgements}

We would like to offer our profound thanks to all contributors, whose work is gathered here. We thank the anonymous external reviewers and are very grateful to Martin Stokes for his moral and practical support throughout the preparation of the book.

Without the support of the SOAS Musicology Series Editorial Board, and Keith Howard in particular, without the help and assistance of the music books editor at Routledge, Emma Gallon, and editorial assistant Annie Vaughan, this book would never have come out.

We owe a great debt of gratitude to our sponsors, the Secretary General of Turksoy Professor Duisen Kaseinov and the Ambassador of Kazakhstan to the UK, HE Mr Erlan Idrisov, for offering financial help towards the completion of the book.

We are very grateful to the Kazakh artist Saule Suleimenova for the permission to use her picture "Akyn" (2011) on the cover of our book.

We thank our families for their love and support throughout.

We dedicate this volume to the musicians of the Turkic-speaking world whodespite growing global challenges and crucial social, political, economic, and environmental issues - continue to perform music. 


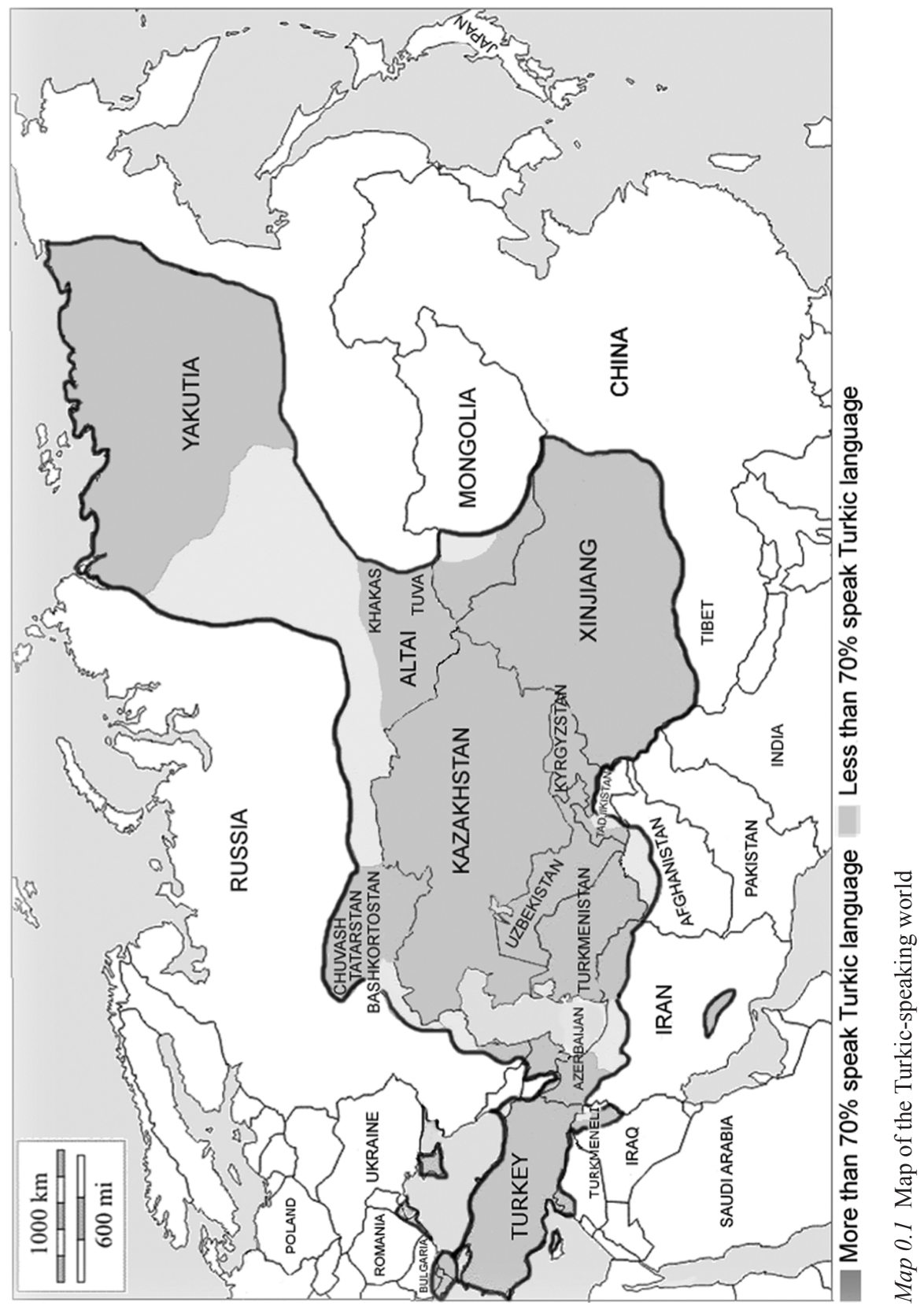




\section{Foreword}

Dear colleagues! On behalf of Turksoy, which is an international organization for studying, preserving and promoting the culture of the Turkic-speaking world, I would like to congratulate you on the publication of this edited book! For the last few years, we have been closely collaborating with ICTM, in particular helping with organization of ICTM Study Group Symposiums, Seminars and Workshops. We were glad to support the 43d ICTM World Conference in Astana 2015. Many activities of the ICTM are very close to our main goals of cultural promotion and dissemination of the Turkic-speaking world. As set out in our mission statement, Turksoy carries out activities to strengthen the ties of brotherhood and solidarity among Turkic peoples with a view to transmitting their common cultural heritage to future generations and promoting it around the world. We are glad to see how today the Turkic-speaking world area is getting better known to the world through music and arts, highly qualified performances and academic evaluations. That, therefore, is one of the reasons why the support of music is one of the main goals of our activity. Many customs and traditions of the Turkic-speaking world have become better known particularly during the last decade. For instance, Navruz celebrations - the pre-Islamic New Year celebration - are the most important traditional events carried out by Turksoy all over the world. Besides these celebrations, Turksoy also organizes various gatherings of scholars, musicians and artists bringing together performers, instrumentalists and singers, poets, writers, theatre, dance and youth ensembles and orchestras of the Turkic-speaking people. We wish you every success in your future undertakings towards the study and promotion of music culture of the Turkic-speaking world.

Professor Duisen Kaseinov

Secretary General of Turksoy

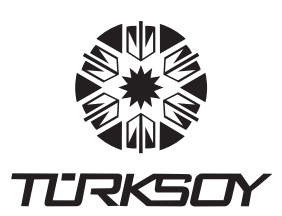

ULUSLARARASI TÜRK KÜLTÜRÜ TEŞKILATI

INTERNATIONAL ORGANIZATION OF TURKIC CULTURE 
Review Copy - Not for Distribution

Giovanni DE ZORZI - University "Ca' Foscari" of Venice - 08/02/2018 


\section{Giovanni DE ZOP
Foreword}

It is a great pleasure to introduce this edited volume. It is the work of a diverse group of scholars. It is the work of scholars reflecting on diversity in the Turkic world itself, too. Until recently, such a project would have been very hard to imagine. Throughout the Cold War, the Soviet Union and the modern Turkish Republic regarded one another with undisguised hostility. Within the Soviet Union, divide and rule policies amplified the cultural differences between the Central Asian republics. In Turkey, the Central Asian and Soviet Turkic minorities were known largely through the work of cultural associations run by emigrés, dissidents and refugees. The pan-Turkic traditions of scholarship, inaugurated in the Ottoman period by scholars such as Ahmet Ağaoğlu, had largely been forgotten, or become the preserve of a handful of right-wing nationalists. I would hear much in those days, though, about Central Asian shamanism, about Central Asian long-necked lutes, about the Central Asian ancestors whose legends, epics, cults and dances had supposedly left their traces on those of today's Anatolia. I remember a visit in 1986 with a distinguished Turkish folklorist to one of Istanbul's Kazakh cultural associations. I can still remember the faint tang of yoghurt and salt in the milky tea we drank. We sat and exchanged thoughts about Turkic dialects, vocal techniques and long-necked lute styles, about cuisine, horses and the harshness of life on the steppes. It all seemed very exotic, on a rainy winter's evening in that dingy Istanbul suburb.

Despite such encounters, serious scholarly communication between those living in Turkey and Turkic speakers elsewhere was limited. This had its convenient aspects, on all sides. It fed a myth in Turkey, for instance - a myth that underlined Turkish distinction and a sense of historical mission. Like all myths, it spoke differently to different people. With its appeal to ethnic solidarity and a heroic past, it spoke strongly to the anti-communist right, naturally enough. But it also spoke, via ideas about shamanism for instance, to secularists - or at least those uncomfortable with the Saudi-dominated Islamic norms then making their presence felt. It spoke to the left, too, with its evocation of an inexorable historical progress from the steppes, via the Ottoman conquests, towards European enlightenment and modernity. The myth took shape, as most do, in the absence of systematic scholarly or intellectual exchange.

Twenty-five years on, we are in a very different world. Western European and American scholars are now able to travel and pursue their research with a degree 


\title{
xxii Martin Stokes
}

of freedom around Central Asia. Meanwhile, scholars from Central Asia (admittedly with more difficulty) find research opportunities, publishing venues and jobs in the Western academy. For a new generation of Turkish scholars, close intellectual, religious and economic ties with the post-Soviet Turkic world are now the norm. Mass media have brought the various Turkic languages and dialects closer. If English continues to prevail in scholarly communication, at least in the West, Russian, opening up the ethnographic archive, is more broadly known. There are undoubtedly difficulties - gradients of power and prestige, some old, some new and perhaps growing - that inhibit or complicate communication. But communication there is. Scholarship spanning the Turkic world now seems to be flourishing.

This volume also attests to a kind of ethnomusicology that would have been hard to imagine twenty-five years ago. That is to say, an ethnomusicology that no longer assumes bounded cultural frameworks, or fieldwork carried out by a single person in a single place. Or that approaches Islam in the non-Arab world as a relic, or as an exotic folk practice. Or that is driven by a quest for ethnic authenticity, remote from the pollution of cities. Or that routinely sees mass media in terms of homogenization, or 'cultural grey-out', to use Alan Lomax's well-known phrase. This volume joins the argument for another kind of ethnomusicology, multi-sited and dialogic, at home in today's rapidly changing cities and media environments.

As Razia Sultanova suggests in her Introduction, what is 'Turkic' about all of this remains open to question. Some important contributions to the ethnomusicological literature in recent decades - significant for their transregional and transhistorical emphases - have suggested definable elements of Turkic musical style. For instance, an inclination towards polyphony rather than monophony (Picken), mimesis as opposed to poesis (Levin), ecstatic as opposed to word-carried religious sensibilities (Feldman). A more contemporary feel for questions of 'Turkic' ethnicity and identity makes itself felt in this volume. Musical identity, here, is what specific actors make of it in specific situations. These are situations defined, or at least shaped, by the prevailing play of 'us/them' oppositions, all highly context-specific, all 'discursive', all performative. Needless to say, such questions are politically fraught, in today's Central Asia as elsewhere. Much revolves around the dynamics of very specific situations and conjunctures, as each of the chapters in this fascinating volume shows. The 'micro' emphasis prevails here, naturally enough. An ethnomusicology of Central Asia capable of embracing both broad tendencies, macro and micro, would be ideal, of course. But this volume marks an important step in that direction.

\author{
Martin Stokes \\ London, December 2016
}




\title{
4 From popular tradition to pop diffusion
}

\author{
Jahrī zikr among teenagers in \\ present-day Kazakhstan
}

\author{
Giovanni De Zorzi
}

\section{Introduction}

In this essay I will deal with the zikr (classic Arab dhikr, 'remembering, recollection') of the jahrī ('loud, vocal') type in its particular adaptation observed in 2003 Turkistan and Almaty - both towns of contemporary southern Kazakhstan. There, the function of the $z i k r$ operated on many levels; it was intensively performed by the young devotees of a charismatic Kazakh sheykh newly arrived from Afghanistan aiming to revive the teachings of an old Sufi way, the yasaviyya, rooted in the area but obscured under Soviet rule. Arranged with polyphony procedures, it was performed by an Almaty-based ensemble of classically trained singers that toured in Kazakhstan and abroad. Their repertoire, made up of $z i k r$ and spiritual compositions, was somehow the 'visiting card' of this new Sufi branch. Through audio-cassettes and CDs, this repertoire was diffused, studied, and learned by young communities in other towns of Kazakhstan. Finally, intensively repeated sessions of $z i k r$ were used as a therapy in order to recover teenagers and youngsters from different kinds of addiction during a forty-day seclusion period called chilla inside the motherhouse of the brotherhood, a private residence in the suburbs of Almaty.

In the following pages I illustrate these specific practices by putting them in their historical background. I will first consider the cultural context of the zikr (particularly in Central Asian Sufism), moving then to Ahmad Yasavi, to the historical development of Sufi brotherhood yasaviyya, and to the new branch of the brotherhood founded by sheykh Ismatullah Maqsum as a part of a global re-Islamization phenomenon in the area that took place after the collapse of the USSR in 1991. I will then move to its vocal repertories, transcribed here in order to show their simplicity compared to the richer and more complex Sufi traditional practices in the area. I will focus then on the role of the $z i k r$ as a cure, a therapy to young people suffering from various types of addiction as a reconstruction of the Islamic background for music therapy. I will conclude with some aesthetical and operative remarks on the $z i k r$ itself as a practice.

My work in the field between 2002 and 2003 was linked with the work on Central Asian written sources by Bakhtyar Babadjanov, Sanjar Ghulamov, and Ashirbek Muminov. Among living dervish communities, I've often found the types of $z i k r$ 
that appeared in the medieval treatises they studied. ${ }^{1}$ More generally, the work by Devin DeWeese, Alexandre Papas, Jürgen Paul, and Thierry Zarcone was important. And, of course, the initial inspiration for this project came from research carried out by ethnomusicologists Jean During, Theodore Levin, and Razia Sultanova. ${ }^{2}$

\section{The concept of 'popular culture' in Kazakhstan}

The term 'popular' is very slippery and difficult to define, changing with time, cultures, and regimes, yet in the following pages we should distinguish among at least three principal meanings that the term had in Kazakhstan.

The first one regards 'popular' as the collective and anonymous knowledge of a given community, transmitted by one generation to another through transmission that is very often oral/aural. This meaning of 'popular', typical of anthropology, seems very apt to describe the case of Kazakh culture as it was for centuries before Soviet forced rule in the twentieth century. This regime affected all aspects of social life, including spirituality, culture, and music, under state-sponsored Russian-European values.

The second meaning of 'popular' is linked with politics. As in all parts of the USSR, in Kazakhstan the new concept of 'popular' was deeply influenced by communist theories and had a very strong political value; the people, and the popular culture (narodnaya kul'tura), were 'pure', 'authentic', 'good', and 'positive' compared to degenerated bourgeois culture, and was therefore held up as a model. Yet, such a model was somehow invented and imposed from above by the regime propaganda, suffocating the traditional practices and beliefs of the people.

The third meaning of the term 'popular' is strongly affected by modernity and is typical of the post-Soviet epoch of the following pages: thanks to the phenomena of technical reproducibility and media diffusion, a given object is 'popular' for its numbers, for example when counting sales of sheet music, of recordings, or of spectators who listened to a concert or saw a film. It's very important to note here how this kind of media diffusion had a strong impact on the global learning process, so that we now distinguish between oral/aural transmission - or 'primary orality' - and diffusion, or 'secondary orality'. This is also true in the Kazakh case. Since the $z i k r$ tradition/transmission was prohibited and forcedly interrupted during the Soviet era (as happened to the pilgrimages to shrines or to the cult of the saints, which actually were 'popular culture' in the pre-Soviet era), in the beginning of the 2000s the learning of $z i k r$ became transmitted through the circulation of audiocassettes and CDs, methods typical of a modern 'pop' culture in a system of 'diffusion of knowledge' rather than 'tradition/transmission of knowledge'.

\section{The dhikr: notes for a background}

The Arab term dhikr (j) literally means 'remembering, recollection, repetition remembrance' of the Name of God (Allah) and/or of some of His ninety-nine divine Names, or divine attributes, such as hayy ('Living'), haqq ('True'), qayyum ('Eternal') that, as a whole, are known as al-äsma al-husnā ('the most beautiful 
Names'). ${ }^{3}$ Apart from the repetition of a single Name, or divine attribute, the dhikr can be based on a formula such as the shahada, the Islamic declaration of faith that recites: Là ilāha illa Allah ('There is no divinity except God').

The concept of $d h i k r$ lies at the core of Islam itself, and its centrality is underlined in many passages from the Quran (for example in II: 152; XIII: 28; XVII: 110; XVIII: 23-24; XXIX: 45; XXXIII: 41-42). Meanwhile, the same Quran in itself, the word of God, is considered a remembrance and a warning to human beings; from this perspective, the reciting of Quran passages can be considered the best dhikr. Apart from recitation or repetition of a divine Name as a spiritual practice, dhikr can be performed in an individual or in a collective way; it can be silent, hidden, and inner ( $k h \bar{a} f \bar{l}$ ) or vocal, loud, and manifest (jahrî) and both types can be performed individually or collectively, which happens frequently in Sufi circles (halqa). In fact, because such concepts and practices are central in Islam, by even greater force of logic dhikr is fundamental in Sufism (tasawwuf), that is the mystical practice of Islam.

In the specifically Sufi conception, the 'heart' (qalb) of a human being is compared to a mirror that reflects the metaphysical divine Light (nür). The action of dhikr is compared to the cleaning of such a mirror in order to give it the chance to reflect what it has to be reflected. At the same time, dhikr implies the intimate relationship between the one who remembers and invokes (the dhakir) and the One who is remembered and invoked (the madhkür). To name something means to establish a relationship with what is named, so that the conscience of such an intimate relationship causes joy for the single dhakir. In the communal rite, this phase coincides with the so-called hadra ('presence') in which ecstasy arises among the participants from the shared awareness of His presence.

As a spiritual practice in itself, dhikr is considered to have many virtues. Putting aside for a moment the inner ( $k h \bar{a} f i$ ) type of $d h i k r$, manifesting and sonically expressing the holy words and formulae in the jahri type of $d h i k r$ are 'good' and 'make good'. It is believed that they can cure and heal not only the hearts (qalb) of their performers (dhakirs), but also the listeners, even if they are at a distance either physically or spiritually. Imam Ghafujan - the Imam Khatib of the Masjid-e Qalon in Bukhara - related to me that, according to medieval essayists, only the jahri can touch the soul of a listener navigating among the distractions (ghaflat) of his/her life, just like a sonorous call would wake one who is asleep. From this power emerges two important features: music therapy (as in the case of Kazakh teenage addicts) and aesthetics.

Apart from religious, historical, music-therapeutic, and aesthetical considerations, I would like to situate the dhikr in a musicological perspective. According to ethnomusicologist Jean During it is, in fact, possible to isolate seven levels of dhikr:

1) 'remembering' without verbal support;

2) dhikr silent ( $k h \bar{a} f \bar{l}$, 'silent, secret, hidden');

3) dhikr verbal (jahrī, 'vocal, loud, manifest');

4) dhikr verbal that may constitute an ostinato to a melody by a soloist, or by a choir; 
62 Giovanni De Zorzi

5) melody that includes a formula of $d h i k r$, often as a refrain;

6) melody that gradually becomes a dhikr;

7) melody in which the implicit rhythm suggests the presence of the $d h i k r$, or its dhikr origin. ${ }^{4}$

In such a perspective, dhikr becomes a musicological subject mostly from level 3 to 7 and during my analysis I will refer always and uniquely to such kind of $d h i k r$.

\section{Zikr among Sufi communities in Central Asia}

In Central Asia, there were (and still are) two main methods for the zikr (local pronunciation of the Arabic term $d h i k r$ that I will adopt from here onward): the jahri method and the khäfi method; the virtues of both are explained in Islamic treatises. ${ }^{5}$ Throughout history, the two methods were considered distinct schools, called jahriyya and khaffiyya. The first was commonly, but inaccurately, related to the yasaviyya Sufi brotherhood, mostly composed of nomadic and Turkic-speaking people, while the second was connected with the khwäjagan/naqshbandìya brotherhood, comprising mainly sedentary and Persian-speaking peoples.

In order to arrive at our teenager communities in Kazakhstan, it seems important to concentrate on the jahri method and to note that for its practitioners this means first of all to practice $z i k r$ according to the great variety of forms and rhythmic patterns of zikr jahrī, which in Central Asia and among Uighurs flourished to a great degree of complexity. Actually, the most famous among scholars and ethnomusicologists is probably the so-called zikr-i arra (modern Turkish zikr-i erre, Arab zikr $i$ minşari), the 'zikr of the saw'; apart from this, the four most basic types of zikr can be classified by the accentuation number of their verbal formulae as 1-2-3-4 zarb's (yek zarb, do zarb, se zarb, chahār zarb, i.e. 'one-beat', 'twobeat', three-beat', 'four-beat').

Second, following a jahrī method may imply the practice of $s a m \bar{a}$ ' and raqs- $i$ $\operatorname{sam} \bar{a}$ ', i.e. 'listening' ( $\operatorname{sam} \bar{a}$ ) to mystical poetry sung by the $h \bar{a} f i z(\mathrm{es})$ and the physical 'movements' (raqs) that can arise from such a listening. Although the dervishes nowadays emphasize this purely vocal trait, nevertheless the presence of music and musical instruments (as in $s a m \bar{a}^{\prime}$ that flourished in other areas in the world of Sufism) is documented in treatises and reports from the past, as well as in interviews that I carried out during my fieldwork.

Third, because the object of listening is mystical Sufi poetry composed by the great Sufi saints/poets of the past, the jahri method requires the presence of experts called $h \bar{a} f i z(\mathrm{es})$ that sing this repertoire during particular phases of the $z i k r$. It is noteworthy that, outside of the strict brotherhood circles, häfiz(es) often had a musical performing career and that some poems from their repertoires are the same texts used in Central Asian classical music (maqom, muqam).

Finally, $h \bar{a} f i z(\mathrm{es})$ and, among women, otin-s can 'sonically' cure and heal participants in rituals that have various names from place to place. It is widely believed that jahrī can 'do good' for listeners and performers. Among these practices is one called chilla (from Persian cihil, 'forty'), the forty days of seclusion and retirement 
from the world that a dervish may be asked to practise. As we will see in the following section, the chilla was widely practised (with a new meaning and a new task) among the Sufi teenagers of Kazakhstan.

\section{Ahmad Yasavi and his heritage}

Afghan-born sheykh Ismatullah Maqsum came back to Kazakhstan, the land of his parents and ancestors, in order to revive the teachings of the yasaviyya brotherhood and its founder, Ahmad Yasavi (b. Sairam, 1103, d. Yasi, 1166-7). It may be useful to remember here that Yasavi was both a spiritual leader and a Turkishlanguage Sufi poet, and that his poetry is still very 'popular' (in the first meaning of the term) among Turkish language peoples.

Information about his life is scarce, and separating biography from hagiography and legend is often difficult. He was the son of sheykh Ibrahim and Karashah-ana, both of whom lived in Sairam, in what is today Southern Kazakhstan. Their tombs were for centuries places of pilgrimage (zyara $t$ ), still visited today. According to the most common story, Yasavi lost his father at the age of seven and his family moved to Yasi, now Turkistan, where he began his education as a disciple of Arslan Baba. Later he moved to Bukhara, in present-day Uzbekistan, where he became a disciple of the great Sufi sheykh Yusuf Hamadani (d. 1140), together with 'abd-ul Khaliq Ghujudwani (d. 1220), becoming one of his four delegates (khalifa). He returned to Yasi in 1160, when he retired in prayer and seclusion in an underground complex still visible today. Six years later, in 1166, he left this low world (dunya).

This reconstruction of the life of Yasavi is the most common in Central Asia in all cultural milieus. Its source lies in the few pages that Maulana Fakhr ad-Dīn 'Al Husain al-Waīz Kashifĩ wrote about Yasavi in his Rashahat 'ayn al-hayat, ${ }^{6}$ a hagiographic work of the masters of tariqa-i khwajjagan ('the way of the Masters'); after Bahā ud-Dīn Naqshband (d. 1389) it will be called naqshbandīyya for its eponym. According to critics, the short passage was written in order to portray Ahmad Yasavi as a student of the khwäjagan line. This common biography was recently heavily criticized by Ashirbek Muminov; according to the Uzbek scholar, Ahmad Yasavi never went to Bukhara, and never studied with Hamadani, but, rather, always remained in Kazakh areas and the yasaviyya brotherhood stemmed from mubaydiyya, one of the most radical Shi' ite sects. ${ }^{7}$

After his departure from this world, Yasavi's tomb became a place of pilgrimage for the Turks of Central Asia and the Volga region. A sumptuous mausoleum was erected around his tomb by emperor Timūr (Tamerlane, 1336-1405), thanks to the architect Mavliana Ubaidulla Sadr or Khwaja Hosein Shirazi. Deserted during Soviet rule, it was restored, reopened as a museum and declared a World Heritage Site by UNESCO in 2002.

Yasavi's work is as elusive as its author, and was probably composed by different authors from different epochs. There are many works attributed to Yasavi but the most famous is undoubtedly the divān-i hikmat, which can be defined as a collection (divān) of aphorisms (hikmat) in the Chagatai Turkish language, using quatrains of seven or eleven syllables. The content of the verses revolve around spiritual themes such as divine love, the Prophet, loyalty to tradition (sunna), and the vanity of 
this low world (dunya), with many eschatological reflections and admonitions. As a consequence of these themes, the divann-i hikmat is full of spiritual exhortations to practice religion, renounce the world, and pursue an ascetic life.

The compositions of divann-i hikmat were probably orally transmitted and gathered in a collection of lyrics around the fifteenth century; the first manuscript dates from the seventeenth century while the first edition was printed in Kazan in 1887. Through the centuries, Yasavi's work became widely known among Turkicspeaking peoples, from the Ottoman-Turkish area up to Eastern Turkestan (today Xinjiang). Widely read and commented upon, it influenced many popular Central Asian Sufi poets, the most famous being Babārahīm Mashrab (1640-1711). ${ }^{8}$

From Yasavi's spiritual teachings stemmed a brotherhood (tariqa) called yasavìyya. ${ }^{9}$ The first delegates (khalifa) were Hakīm Atā (d. 1183) and Sa'id Atā (d. 1218) followed by Zangī Atā, Uzūn Hasan Atā, Sayyid Atā, Ishāk Atā, and Sadr Atā. The yasaviyya carried his teachings, and very often Islam, into the Volga region, Khwarezm, present-day Eastern Turkey, and Chinese Xinjiang. Yet, a process common and recurring throughout the history of the yasaviyya is its confusion with heterodox wandering dervishes (qalandār) or its absorption into pre-existent Sufi orders that were more deeply rooted in a given area.

According to the shajarat al-atrāk composed in the sixteenth century, one of the first delegates (khalifa) of Ahmad Yasavī was Sayyid Atā, who lived during the fourteenth century. Atā converted the Uzbek Khān and leader of the Golden Horde, to Islam, beginning with the Islamization of nomadic Turkic peoples. ${ }^{10}$ From the same Sayyid Atā would flourish a new branch of yasavī, the ată 'iyya in Khwarezm.

Between the fourteenth and fifteenth centuries there would be a certain competition with khwäjagan/naqshbandīyya, the 'other' great Sufi central Asian brotherhood that criticized various aspects of yasavi doctrines and practices, particularly zikr jāhri and sama $\bar{a}^{\prime}$, giving new ground to the controversy between jahriyya and khäfíyya. Yet later, in the sixteenth century, many naqshbandī masters defended the legitimacy of yasavi practices, such as the well-known naqshbandī Ahmad ben Maulana Jalal ud-din al-Kasani ad-Dahbidi, better known as Mahdum-i A'zam (d. Kashgar, 1542), in his epistle risala-yi sama 'iya. For this reason, from that treatise onward, many dervishes had a double affiliation, being both naqshbandī and yasavi at the same time, as I had the chance to observe many times during my research in Ferghana.

Between the sixteenth and seventeenth centuries, the yasaviyya somehow disappeared from the urban centres, leaving space for the naqshbandiyya and assuming a 'rural' and popular (this time in the social strata sense of the term) role, particularly among nomadic peoples. According to Thierry Zarcone, the successors of the yasavi masters acted as 'intercessors' for pilgrims in the shrines of Sufi saints. In this form, the yasaviyya survived until today, despite Soviet repression denouncing its 'feudal, reactionary and clerical' character. ${ }^{11}$ In fact, the yasaviyya is still diffused throughout the Central Asian region, while in Xinjiang it became mingled with the practices of wandering qalandār dervishes. According to anecdotes told to me during my fieldwork, the yasaviyya doesn't exist yet in Turkey; however, many pilgrims arrive from Turkey to pay homage to the saint in his mausoleum/museum in Turkistan. 


\section{Modern Kazakhstan against a traditional Central Asian background}

I arrived in Kazakhstan after a period of field research ${ }^{12}$ in a more traditional environment, the Uzbek part of the Ferghana valley and southern Kyrgyzstan. In both locations, I had the chance to notice that the rituals of the jahri school were mostly practised by middle-aged and rather old men called oq saqol ('white beards'), who, for the major part, were peasants. In such zikr rituals, the presence of musical and poetical elements were an important trait: over the ostinato of the zakirs performing elaborated rhythmical zikr-s, the hafiz-es sang poems of mystical content composed by well-known Turkic language poets from the Middle Ages.

When I moved to southern Kazakhstan, namely Turkistan and Almaty, I found a very different situation: a large part of the Sufi circles diffused here and there in the area were, in fact, populated by teenagers, often high school or university students, performing only two kinds of jahrī zikr. Moreover, it was difficult to find traces of a 'traditional' oq saqol Sufism, represented in the area mainly by strict naqshbandī dervishes who did not practise loud (jahri $)$, but instead only utilized silent $(k h \bar{a} f i) z i k r .{ }^{13}$ The reason for such a young presence may have arisen from the vacuum of several generations created by the Russian, then Soviet, politics of forced secularism that repressed all spiritual activities on Kazakh territories (Shamanism, Buddhism, Islam, and Orthodox Christianity). After independence, young people most likely 'filled the gap' left by previous generations. In this sense, they turned to neglected traditions, as is the case of Ahmad Yasavi and the yasaviyya Sufi brotherhood.

\section{The strange case of Sheykh Ismatullah Maqsum}

It was in this environment that the case of the Sufi sheykh Ismatullah Maqsum developed. Born around 1938, he was 65 years old at the time of our meetings in May 2003. His grandfather (Shalklar Awliya) and his father were both members of the Yasavi Sufi brotherhood. In particular, his father, Abd al-Gaffar Qari, opposed Soviet rule in the Kazakh territory and participated in the jihad against the Red Army led by Aqmirza Damulla. After the defeat of the Kazakh revolt, he had to quickly move to Afghanistan in order to escape from Soviet repression; for this reason Ismatullah Maqsum was born in Mazar-i Sharif, where he then accomplished his studies under his father's direction. As he told me, he later travelled all around the area, including India, Iran, and Pakistan. Yet, according to interviews made with scholar Habiba Fathi, during his youth he fought the Russian invasion as a young mujahidin with the Afghan resistance, but after 1992 he had to take refuge in Pakistan. ${ }^{14}$ As he told me, his father asked him to come back to Kazakhstan in order to take Islam back to the fatherland. For this reason after the 1991 dissolution of the USSR and the new independence that guaranteed a certain freedom of religious practices, he came back to Kazakhstan on the occasion of the 'Congress of the Kazakhs of the Diaspora' in Turkistan. After a while, he reintroduced the yasaviyya and founded an official association called 'Faith, Knowledge and Way' (Senim, Bilim, Omir) teaching a particular type of zikr jahri and studying the works 
(Hikmatlar) of the great poet and Sufi saint Ahmad Yasavī (d. Yasi, Turkistan, 1166). In that period of new independence, the authorities considered the adherents of this new tariqa yasaviyya, together with the new sprouts of Sufism in the area, as 'Wahhabi sympathizers'; ${ }^{15}$ this led to the arrest of some of their spiritual authorities, who were released after some time. According to scholar Habiba Fathi, it was likely Maqsum's rare capacity to mobilize the youth ${ }^{16}$ that troubled the political and religious (DSMK) authorities.

Hosted in the private house of a devotee in the green suburbs of Almaty, called Qara Su Medrese (also known as Sakarim Medrese), little by little he founded a network of private centres and mosques where this kind of $z i k r$ was intensely and daily practised. The new school grew in the principal towns of Kazakhstan, filling the vacant and unoccupied mosques and spiritual centres with a new generation of teenagers that were educated and newly Islamised, mainly in the Qara Su Medrese.

In the strict environment of the Qara Su Medrese motherhouse, the system of the teenagers' education depended mainly on 'secondary sources' such as CDs and audio-tapes of zikr and sacred hymns (ilähi, du'a) to which devotees listened intensively, learned by heart, and repeated during their daily session of $z i k r$. The tapes were recorded by a choir called Ensemble Yasavi Tobo, consisting of Maqsum's devotees, who were often also Conservatory students. They attained a certain level of success and travelled abroad spreading the message. Their repertoire consisted of $z i k r$ phases intertwined with sacred hymns, arranged and harmonized according to Western canons. Such recordings give a perfect aesthetic example of the new Kazakhstan in itself, between local tradition and the Western world. From the musical structure (the harmonization of a traditional oral repertoire according to Western criteria), to the polished studio recording in itself and the pose of the ensemble for the cover - all dressed in Kazakh-flag blue shirts - the complete phenomenon can be viewed as a perfect image, a little miniature, of the new Kazakhstan in itself, between tradition and Westernization through Russian influence.

Finally, the zikr jahri taught by Sheykh Ismatullah Maqsum, together with the brand-new composed repertories of the Ensemble Yasavi Tobo, seemed to comprise the tools of a re-Islamization phenomenon that took place throughout Kazakhstan, even in the old centre where Ahmad Yasavī himself once lived, namely present-day Turkistan.

\section{Toward a description of the new zikr jahrī of Ismatullah Maqsum school}

The new version of zikr jahri proposed by Sheykh Ismatullah Maqsum was simple, effective, and lacked the great typological variety of $z i k r$ I found elsewhere in Ferghana, or in a 1995 video of the octogenarian yasavī hāfiz Ghulām Āta Normatov filmed in Turkistan by scholar Nasrutjon Hamrakulov. Instead, the new proposed version was based only on the zikr-i arra ('zikr of the saw') and on the zikr-i halqa ('zikr of the circle'), which is of the upright, erect type elsewhere called qiyyami. These two types of $z i k r$ mingled and interacted with some vocal repertories that, in the Ensemble Yasavi Tobo, served as a model for the zakir-s 
scattered all over the Kazakh area, performed with pitched operatic voices harmonized in a Western musical style. Globally the zikr ceremony consisted of two principal phases that were introduced and closed by long phases of $d u$ ' $a$ ('free invocations') and requests of forgiving (istighfar):

1) In the zikr-i arra the zakirs created an ostinato in a rhythmic cycle of $8 / 4$ on closed-mouth syllables $(M m h, m m h, m m h, m m h)$ violently rotating the head from the right to the left. ${ }^{17}$ When the ostinato was established, the soloist's voice began the shahada formula (also known as tahlīl): La Ilaha Illa Allah ('there is no divinity except God'). At the end of each cycle of 8 the whole community accented, by shouting, the Illa Allah phrase. Afterwards the ostinato alternated different spiritual texts sung by different soloists.

2) In the zikr-i halqa the participants stood up. Standing erect (qiyyam), they crossed their arms, hands on their elbows, and disposed themselves so that the right side of their bodies was toward the centre of their circle (halqa). Then they began to sing the formula Allah, Allah, Allah Hī / Allah Eyy. ${ }^{18}$ ('God, God, God He / God, the Living'). Pronouncing the first part of the formula, they leaned their bodies to the left, and while when pronouncing the second part (Allah Eyy), explosively and sforzando, they converged together, heads and sides, to the right, i.e., the centre of the circle.

In Examples 4.1 and 4.2, I propose a musical summary of the entire ritual, by putting aside the long phases of $d u^{\prime} a$ ('free invocations') and requests of forgiving (istighfar).
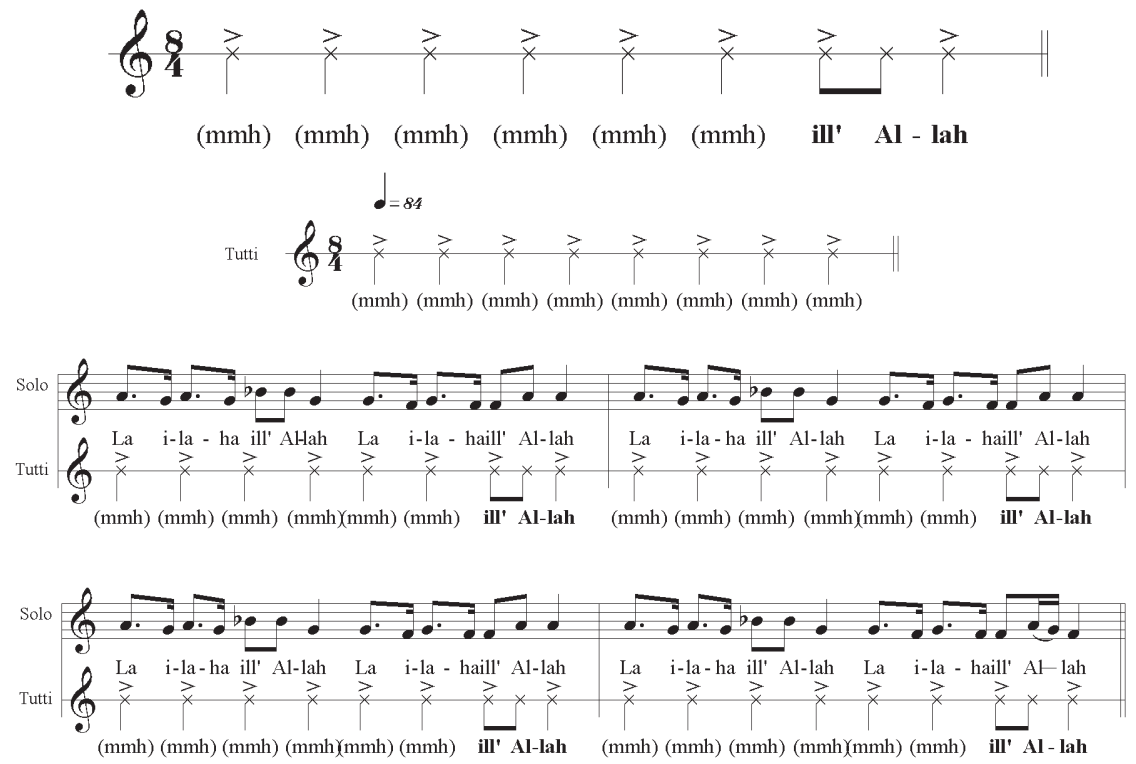

Examples 4.1 and 4.2 Ostinato of the zakir -s and sacred hymn 
68 Giovanni De Zorzi

Over the ostinato of the zakir-s (Example 4.1) began the sacred hymn (Example 4.2) diffused throughout the whole Central Asian area: Hazbi Rabbi Jalla Llah / mo (Ar. mā) fi qalbi ghairuLlah / Nuri Ahmad salla l-Lah / La ilaha illa 'Llah ('I rely on God, be exalted! / There is nothing in my heart except God / Light of Muhammad, God pray on him / There is no divinity except God').

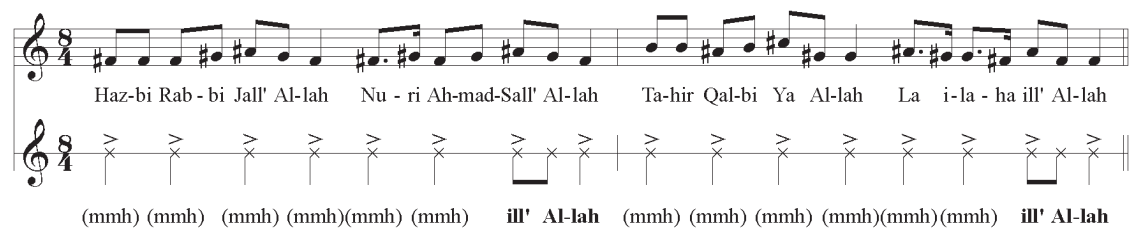

Example 4.3 Zikr-i Halqa phrase

The Zikr-i Halqa phrase in Example 4.3 was based on the words Allah, Allah, Allah Hu, Allah Eyy ${ }^{19}$ and was executed as shown in Example 4.4.

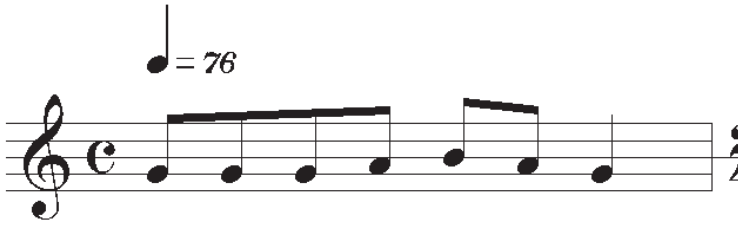

$\mathrm{Al}$ - lah $\mathrm{Al}$ - lah $\mathrm{Al}$ - lah $\mathrm{Hu}$

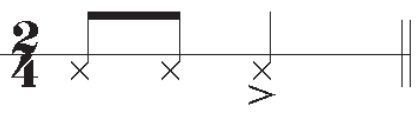

Al - lah Hayy

Example 4.4 Execution of Zikr-i Halqa phrase

During the phrase in Example 4.4, it was also possible to recite a very fast variant based on the words Allah Hu, Hu, Eyy. The phrase Allah Hu, Hu was uttered as each person leaned his body toward the outside of the circle, then the explosive Eyy sounded as everybody leaned together toward the centre of the halqa.

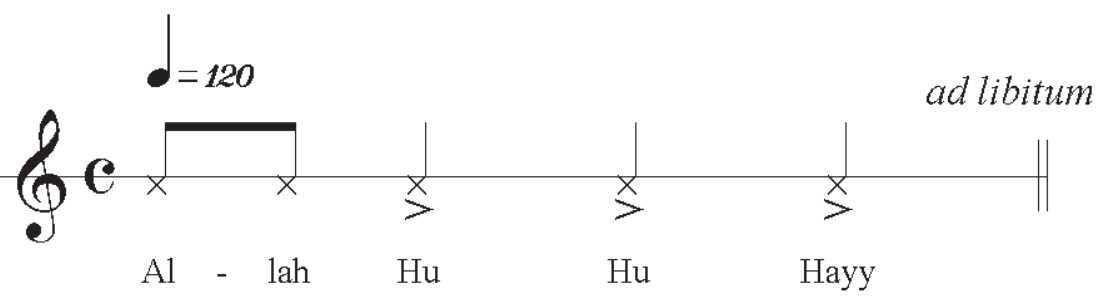

Example 4.5 Fest variant of Zikr-i Halqa phrase

This group of zakir -s mixed traits of ancientness and modernity that were rather peculiar: youngsters in basketball garments, in the style of African-American rappers, practised the $z i k r$ notated above in a lacerating vocal emission such as we can find among the South Siberian area and among present-day examples of $z i k r$ 
jahri in Chinese Xinjiang. ${ }^{20}$ The absence of the hăfiz-es was rather striking; the task of reviving the fire of the $z i k r$ (or to placate it) was here transferred to the exhortations of the leader of the zikr circle (halqa bashi) and to the newly composed vocal repertoires of spiritual argument, which were learned by the zakir-s scattered throughout Kazakhstan through audio-cassettes recorded by the ensemble Yasavi Tobo.

\section{Zikr as a therapy against addiction}

The socio-economic situation of modern Kazakhstan itself is rather different from the other four formerly Soviet republics of Central Asia. Kazakhstan is presently the richest of the five republics, the one that maintained more or less intact all of its economic links with Russia, and the one where a rather 'Westernized' way of life is more widely diffused. Perhaps due to these factors, contemporary Kazakhstan, more than elsewhere in the territories of the former USSR, has to face many of the typical problems of modernity, among them alcoholism and consumption of illegal drugs, particularly heroin.

The Qara Su Medrese offered hospitality to many teenagers and youth with addiction problems, mostly with drugs but also with alcohol. The sheykh advised them to stay in seclusion for a period of forty days (thus actualizing the classical Sufi chilla), practising the zikr before dawn, during the mid-morning, after the noon collective prayer, in the mid-afternoon, after the sunset and during the night. These sessions produced strong effects, and I had the chance to observe the intense altered states that occurred among the practitioners (zakir).

According to the interviewees, in the environment of the medrese they gradually stopped their abuses and little by little rediscovered the traditional values intrinsic to the daily life of a Muslim. Moreover, in the words of one teenager, the aesthetic values of the jahri method appealed to him; according to him, the $z i k r$ had to be loud, sonorous, open, public, visible, and beautiful in order to rebalance all the bad and horrible things of this world that openly and publicly happened. Similarly, someone in the more traditional and conservative Sufi circles of oq saqāl in Fergana valley told me that one of the great virtues of the jahri lies in the effect of beauty that it can induce, even in the heart of outside listeners.

\section{Sonorous therapies in the world of Islam}

This particular therapy, administered by the sheykh to the youth, brings us to the use of sound as a tool for healing, which has deep roots in Islamic culture (as well as to the heritage of Greek-Hellenistic theories).

According to Sufi conceptions, the human being is a harmonious unity of body (qalab, tan), soul (nafs), and spirit (rūh). From this perspective, illness was considered a rupture of such equilibrium. At the same time, physical (vibrational) and metaphysical, music could cure, heal, and re-harmonize the disharmonies of a human being. From this particular conception we have different cases of music therapy in Islam: it seems here worthwhile noting the following passage from the 
70 Giovanni De Zorzi

Kash al-mahjūb ('the unveiling of the Veiled') by al-Hujwīrī (? - d. Lahore, 1072/76), one of the oldest Persian treatises on Sufism. In the chapter dedicated to the Sufi practice called $s a m \bar{a}$ ' ('listening, audition, spiritual concert') al-Hujwìrī states that in the hospitals of Rūm (i.e. Byzantium) the patients listened to a string instrument called anghalyūn:

The sick are brought to it two days in the week and are forced to listen, while it is being played on, for a length of time proportionate to the malady from which they suffer; then they are taken away. ${ }^{21}$

After many centuries, in 1651, the Ottoman historian Evliyā Çelebi (1611-1684) described the hospital for lunatics founded in Edirne by the sultan Bayazid II (1481-1512) and noted that three singers and seven musicians were salaried and visited the hospital three times per week. They played six different melodies; this 'nourishing of the spirit' alleviated the patients' sufferings. ${ }^{22}$ The hospital was active until the beginning of twentieth century, when the newly born Turkey decided to reject all cultural traditions of the Ottoman past, but the site and its relics are still visited by tourists, while nearby shops sell 'New Age' CDs with supposed music-therapeutic virtues.

Ethnomusicologist Jean During, expanding an observation made by the late AnneMarie Schimmel, writes that the Shefă'iyya hospital of Devrigi, in Anatolia, founded in 1228 , had a wonderful hall where the sound of water drops falling in a basin was intended to cure the insane. ${ }^{23}$ Scholar Michael W. Dols, by analysing the accounting books of the Mansuri hospital of present-day Cairo, Egypt, notes the salaries of the musicians that played music for the patients each day. In 1648, the Ottoman historian Evliyā Çelebi, a musician himself, visited the Mansuri hospital and noted that concerts were given three times a day as a form of medicine. French traveller Jean Baptiste Tavernier (1605-1689), visiting the right wing of the exterior part (Bìrün) of the Sultan's palace in Constantinople, observed a hospital where many were cured with a 'weird' vocal and instrumental music. ${ }^{24}$ Such examples of clinical practices, together with passages from contemporaneous treatises, demonstrate a well-established cultural background that had analogs in Sufi practices such as dhikr or samā'.

\section{On some aspects of $z i k r$ jahrī}

As a spiritual practice in itself, the $z i k r$ jahri clearly demonstrates two traits: first, the particular rasping sound required by the $z i k r$ is clearly linked with the breathing, which in itself becomes a sonorous and hoarse component; second, the fervour of the collective jahri zikr produces internal warmth in the practitioner, sometimes described as an 'inner fire'. Both traits had already been explained in medieval Sufi treatises and, regarding attention to the breathing, are excellently expressed in the motto hosh dar dam ('control on the breathing') in the khwäjagan/naqshbandī way. During my fieldwork elsewhere in Ferghana, the practitioner was invited to 'lift up' the vital breathing (dam) from below the navel (qindiq) up to the head.

It seems also important to underline the physical component of the zikr jahri according to the interviewees, the body (qalab, tan), 'soul' (nafs), and 'spirit' 
( $r \bar{u} h$ ) work together: the sweat and the tears that appear during the most vehement phases, open and remove the spiritual occlusions of the zakir.

On a more abstract level, in the inner fire of $z i k r$ we can identify a sort of traditional spiritual alchemy. It is believed that the fire of $z i k r$ 'cooks' the practitioners. An analogous cooking process happened among the mevlevī Dervishes, during the period of the 1001 days that every postulant Dervish passed in a mevlevi Sufi centre, ${ }^{25}$ beautifully expressed by the well-known story of the cook and the chickpeas that we find in Masnavi-i Mana'vī composed by Mowlana Jalāl-ud Dīn Rūmī (1207-1273): the chickpeas, that is the postulants the disciples (murīd) complain of burning and suffering in the boiling water. The cook (the sheykh, the master) reassures them, answering that he too passed through a similar process, claiming that this happens in order for them to mature and ripen, from green and raw (ham) to mature and cooked (pokhté) in the fire of Love ( 'ishq).

\section{Conclusions}

The multifaceted case of the yasavi zikr among youth and teenagers in Southern Kazakhstan summarizes many aspects and contradictions of present-day Kazakhstan, suspended in a difficult equilibrium between an erased and censored past and an uncertain present, between tradition/transmission and 'pop' media diffusion, between modernity and past, East and West, teenagers and 'white beards' (oq saqol), between the nuances of old Sufi traditions and the simplifications considered necessary for the present.

If from an anthropological and sociological view the Kazakh case gives us an opportunity to distinguish between various meanings of the term 'popular culture', the nonchalant use of the tools of modernity in order to spread a 'traditional' Islamic message made by the Yasavi Tobo Ensemble also suggests that, given the lack of popular oral/aural traditions, pop diffusion through mass media could be considered the main means of disseminating knowledge and religious themes, and - very probably - of re-Islamization in the area. In this sense, we can note here the actualization of the intent of many medieval Sufi spiritual compositions. The unconstrained and unembarrassed use of the media by the sheykh in order to spread to the masses the message of Islam and Sufism provides another example of culture moving between popular and pop, in an updating of the classical $d a$ 'wa ('call, invitation').

The ensemble Yasavi Tobo, now also on YouTube, ${ }^{26}$ can also be seen as the first Kazakh example of a 'pop' Islamic genre. This genre, which has quickly spread all over the world from the first decade of 2000, uses Western musical language and media in order to convey classical religious and devotional themes mainly to a young audience. Examples include the successful singer Sami Yusuf (1980-) and his imitators and followers, or the TV festival Munshed al-Sharjah in which singers (munshed) of the religious traditional genre (inshad) are voted on by the public through phone-in voting, modelled after Euro-American contests like The X Factor. ${ }^{27}$ This takes us to the globalized trend of Islamic pop singers who are currently flourishing, using pop language (style, song-form, musical instruments and tools, recording studios, dresses, haircut, videos, tour managers) in order to 
transmit Islamic beliefs through their performances to young audiences. Can this be considered a new 'tradition'? After all, the etymological sense of tradition is transmission, and an important aspect of the concept is that it is not static, but always moving, shifting, and changing.

Out of the Kazakh case, such a use of mass media for religious/spiritual purposes is a question that lies at the core of Islam itself, between popular and pop, chai and Mecca Cola, TV advertising with old ilähi in the background and TV contests with phone-in voting for young Quran reciters during the month of Ramadan. The drastic conclusion would be that Islamic culture has not yet found a strong and autonomous way to propose its values; but in fact, interaction between lands and languages recurs throughout Islamic history, alternating phases of attraction and repulsion. The whole process constantly evolves so that the only, very provisory, conclusion we can make is that our questions are far from resolved.

\section{Notes}

1 See Babadjanov and Ghulamov (2004). Among the treatises on zikr jahrī a few are notable: Anonymous, Risala-yi dhikr-i Sultan-i 'arifin, MNS IVAN Uz (Institut Vostokovedenie Akademii Nauk Uzbekistan) 5455/1; Ishak b. Hadrat Isma'il-Āta, Hadikat al arifin, Oriental Institute, Academy of Sciences, Republic of Uzbekistan, manuscript N 11838 (fourteenth century, rewritten around the first half of the eighteenth century); Akhmad ben Maulana Jalāl ad-dīn al-Kasan̄̄ ad-Dahbid̄̄ (Mahdum-i A'zam, d. 1542), Risala-yi sama 'iya, MNS IVANUz, N 501/11, ff. 13b-3b; Khwāja Muhammad Parsa, (d. 1419) Majmua ' al-fatawa, MNS IVAN RUz, N 3010/x, ff 179a-186a; Fazlallah b. Muhammad b. Ayub (end of the fifteenth century, beginning of the sixteenth century), Fatawa-yi sufiya fi tariqi-l-iya, MNS. IVAN RUz, n. 7132; 'Ali b. Muhammad b. 'Ali al-Muhtari, al-Khwarazmi al-Kubravi, Fatawa-yi 'Aliy, SVR (Sobranie Vostochykh Rukopisei Akademii Nauk Uzbekskoi SSR) VIII, N 5870, 5871 (N 7177/III, 9138); Mawlāna MīrKhāl al-Dīn al-Yarkāndī, Hidayāt Namā (1730), Ms. IVAN Uz, 1682/I, f. 45b.

2 I would also like to thank here the supporting team of the Tashkent IFÉAC (Institut Francais d'Études sur l'Asie Centrale) that helped me in many ways and to remember the friendly and warm presence of the late Giorgio Messori, Italian Language and Literature Professor at the Italian Embassy in Tashkent.

3 It seems important to note here that to the canonical list of ninety-nine Divine names/ attributes must be added here the pronoun $h \bar{u}$ ('He'), often associated, in its evocativeness, with $d h i k r$ phases combined with breathing techniques.

4 Jean During, Musica ed estasi: L'ascolto mistico nella tradizione sufi, new updated version edited and translated by Giovanni De Zorzi (Roma, Squilibri, 2013), 164. Original edition Musique et extase: L'audition mystique dans la tradition soufie (Paris, Albin-Michel, 1988), 168.

5 See note 1.

6 Fakhr ad-Dīn 'Al Husain al-Waīz Kashifî, Rashahāt 'Ayn al-Hayāt, ed. 'Ali Ashgar Mu'īniyān (Teheran, Majmuah-i Mutun-i Qadim va Ahval-i Danishmandan va Irfanan, 1977), 17.

7 Ashirbek Muminov, "Mübeidiyye-Yasaviyye alâkası hakkında", Bir, I, Istanbul (1994): 115-123.

8 On the poetic legacy of Yasavi in Mashrab and on the poetical works of wandering qalandār dervishes, see: Alexandre Papas, Mystiques et vagabonds en Islam: portraits de trois soufis qalandar (Paris, Éditions du Cerf, 2010).

9 I follow here Thierry Zarcone, "Yasawiyya" in The Encyclopcedia of Islam (E. J. Brill, Leiden, 2001, XI), 294-296. 
10 On the whole phenomenon see: Devin Deweese, Islamization and Native Religion in the Golden Horde: Baba Tükles and Conversion to Islam in Historical and Epic Tradition (University Park, PA, Pennsylvania State University Press, 1994).

11 Thierry Zarcone, "Yasawiyya", 295.

12 This research took form in my $\mathrm{PhD}$ thesis: Gli zikr della confraternita sufi Yasaviyya nella valle del Fergana (Uzbekistan, Kazakhstan, Kirgyzstan) (PhD dissertation, University "La Sapienza", Rome, 2006) and published articles on selected topics: "Incontri di dervisci a Karkhidon. Lo zikr ('menzione, ricordo') dei Nomi Divini in area centroasiatica", Phoenix. In domo Foscari, (Scriptaweb, Napoli, 2008, 1), 89-128. "Con dervisci naqshbandî-jahrînella valle del Fergana" in Con i dervisci: Otto incontri sul campo, edited by Giovanni De Zorzi (Milano, Mimesis), 173-202.

13 Here I refer to the remote Kush-Ātà centre, and to the many little centres of naqshbandī dervishes under the spiritual direction of Ibrahim Sheykh and Qurban 'Ali. I visited and interviewed Ibrahim Sheykh for my article, "Con dervisci naqshbandî-jahrî nella valle del Fergana", 188-190. Moreover, in Habiba Fathi, "Les réseaux mystiques au Kazakhstan: entre dhikr et militantisme?" in Cahiers d'Asie Centrale (Tashkent/Aixen-Provence, Edisud, 2007 n. 15/16): 233-234, 237, 248.

14 Habiba Fathi, "Les réseaux mystiques au Kazakhstan: entre dhikr et militantisme?", 234.

15 Wahhābiya is the name given to an Islamic movement founded by Muhammad ben al-Wahhab (1703-1787). His teachings aimed at the return to a pure form of Islam, rejecting all innovations ( $b i d a)$ produced after the third century of Islam. For different historical reasons, in Central Asia the term was adopted as a synonym for 'Islamic terrorist' and 'fanatic'. The fear of mysterious 'Wahhabis' is often the pretext for police control of all people's activity in the area.

16 Habiba Fathi, "Les réseaux mystiques au Kazakhstan: entre dhikr et militantisme?", 235.

17 More specifically, they violently rotated their heads from the subtle centre (lati fa) placed over the right eyebrow, technically called qabaq, to the subtle centre (latif $f$ ) placed over the heart (qalb).

18 Arabic al-hayy 'the Living', one of the ninety-nine Divine names of Allah.

19 Arabic hayy, "Living".

20 The reader can listen to an example of a zikr jahrī of naqsbandī âfaqī dervishes recorded in Yarkend, Xinjiang, in track 12 of the CD attached to Jean During, Musica ed estasi. L'ascolto mistico nella tradizione sufi, 2013; or in the CD Trance 2, Musical Expeditions, Ellipsis Arts, Roslyn, NY, 1995, no. 4010; or in the double CD: The Silk Road: a Musical Caravan, Smithsonian Folkways Recordings, Washington, 2002 (2 CD): 40438 [CD 2, track 19].

21 'Ali ben 'Uthman al-Jullābī al-Hujwīīi, Kashfal-Mahjūb, 'The revelation of the Veiled': An Early Persian Treatise on Sufism, translated by Reynold Alleyne Nicholson (Warminster, E. J. W. Gibb Memorial Series XVII, 2000), 407.

22 Michael W. Dols, Majnūn: The Madman in Medieval Islamic Society, edited by Diana E. Immisch (Oxford, Clarendon Press, 1992), 173.

23 Jean During, Musica ed estasi: L'ascolto mistico nella tradizione sufi (Roma, Squilibri, 2013), 136.

24 Michael W. Dols, Majnūn: The Madman in Medieval Islamic Society (Oxford, Clarendon Press, 1992), 171-173.

25 On this 1001 day period of service: Thierry Zarcone, "La mevleviye, confrérie des derviches tourneurs", in Alexandre Popovic et Gilles Veinstein (eds), Les voies d'Allah: Les ordres mystiques dans le monde musulman des origines à aujourd'hui (Paris, Fayard, 1996), 507.

26 Part of the transcript $z i k r$ is now available at www.youtube.com/watch? $\mathrm{v}=5 \mathrm{~T}$ _eUo0QrtQ. Other repertoires can be found at www.youtube.com/watch?v=3MEmtSYssEo or searching for "ЯСАУИ тобы" in YouTube (webpages visited 18 July 2014).

27 'Iyad Hafez, Munshed Al-Sharjah e il canto religioso islamico (inshad) nella società araba contemporanea, (PhD dissertation, University "La Sapienza" of Rome, 2012). 